\title{
Hepatic Lipid Metabolism in Transition Dairy Cows Fed Flaxseed ${ }^{1}$
}

\author{
H. V. Petit, ${ }^{* 2}$ M. F. Palin, ${ }^{*}$ and L. Doepel† \\ *Dairy and Swine Research and Development Centre, Agriculture and Agri-Food Canada, PO Box 90, Stn. Lennoxville, \\ Sherbrooke, Quebec, J1M 1Z3, Canada \\ †Department of Agricultural Food and Nutritional Science, 4-10 Agriculture-Forestry Ctr., University of Alberta, Edmonton, \\ Alberta, T6G 2P5, Canada
}

\begin{abstract}
Thirty-three Holstein cows averaging $687 \mathrm{~kg}$ of body weight were allotted $6 \mathrm{wk}$ before the expected date of parturition to 11 groups of 3 cows blocked within parity for similar calving dates to determine the effects of feeding different sources of fatty acids on blood parameters related to fatty liver and profile of fatty acids in plasma and liver. Cows were fed lipid supplements from 6 wk before the expected date of parturition until d 28 of lactation. Cows within each block were assigned to 1 of 3 isonitrogenous and isoenergetic dietary supplements: control with no added lipids (CO); unsaturated lipids supplied as whole flaxseed (FL; 3.3 and $11.0 \%$ of the dry matter in prepartum and postpartum diets, respectively); and saturated lipids supplied as Energy Booster (EB; 1.7 and $3.5 \%$ of the DM in prepartum and postpartum diets, respectively). Diets EB and FL had similar ether extract concentrations. Multiparous cows fed EB had lower dry matter intake and milk production, higher concentrations of nonesterified fatty acids and $\beta$-hydroxybutyrate in plasma and triglycerides (TG) and total lipids in liver, and lower concentrations of plasma glucose and liver glycogen than those fed FL and CO. Production of $4 \%$ fat-corrected milk was similar among treatments. Multiparous cows fed FL had the highest liver concentrations of glycogen on wk 2 and 4 after calving and lowest concentrations of TG on wk 4 after calving. Liver C16:0 relative percentages in multiparous cows increased after calving whereas those of C18:0 decreased. Relative percentages of liver C16:0 were higher in wk 2 and 4 postpartum for multiparous cows fed EB compared with those fed CO and FL; those of C18:0 were lower in wk 4 postpartum for cows fed EB compared with those fed CO and FL. Liver C18:1 relative percentages of multiparous cows increased after calving and were higher in wk 4 for cows fed EB
\end{abstract}

\footnotetext{
Received January 30, 2007.

Accepted May 16, 2007.

${ }^{1}$ Contribution number 920 from the Dairy and Swine Research and Development Centre.

${ }^{2}$ Corresponding author: petith@agr.gc.ca
}

compared with those fed $\mathrm{CO}$ and FL. The inverse was observed for liver C18:2 relative percentages. In general, diets had more significant effects on plasma concentrations of nonesterified fatty acids, $\beta$-hydroxybutyrate, and glucose and liver profiles of fatty acids, TG, total lipids, and glycogen of multiparous than primiparous cows. These data suggest that feeding a source of saturated fatty acids increased the risk of fatty liver in the transition cow compared with feeding no lipids or whole flaxseed. Feeding flaxseed compared with no lipids or a source of saturated fatty acids from 6 wk before calving could be a useful strategy to increase liver concentrations of glycogen and decrease liver concentrations of TG after calving, which may prevent the development of fatty liver in the transition dairy cow.

Key words: dairy cow, flaxseed, fatty acids, fatty liver

\section{INTRODUCTION}

Fat is often fed to early postpartum cows to overcome the negative energy balance after calving. The effects of supplemental fat on milk yield and composition, intake, and digestion have been extensively investigated but only a small number of studies have been performed to determine the effects of dietary fat on hepatic metabolism in dairy cows. Douglas et al. (2006) have shown that high fat diets fed to dry cows tended $(P<0.10)$ to decrease liver triglycerides (TG) accumulation, suggesting that high fat diets could decrease hepatic TG accumulation after parturition. Moreover, Rukkwamsuk et al. (2000) have reported that the profile of fatty acids (FA) within the liver is dramatically changed when intracellular adipocyte lipolysis increases, thus changing the composition of fatty acids reaching the liver. Other experiments have demonstrated that dietary fat induces metabolic changes in laboratory rodents such as increased peroxisomal and mitochondrial $\beta$-oxidation of FA (Kumamoto and Ide, 1998), decreased esterification of FA (Malewiak et al., 1988), and altered profiles and clearance of plasma lipoproteins (Lambert et al., 1998). Most of these changes in lipid metabolism of rodents were observed during starvation or negative 
energy balance, which would be similar to the negative energy balance occurring after calving.

There is little information available to evaluate the effect of supplemental fat in the diets of cows before calving. In one study (Skaar et al., 1989) in which supplemental fat was fed to precalving cows, intake of DM was restricted. In a second study, calcium salts of FA were fed in diets that were not isoenergetic (Selberg et al., 2004). Dietary polyunsaturated fatty acids (PUFA) are well known to reduce lipid accumulation in the liver, up-regulate FA oxidation in liver and skeletal muscle, and increase total body glycogen storage (Jump and Clarke, 1999). One recent in vitro study has shown that n-3 (omega-3) FA increase oxidation of FA and the incorporation of FA into cellular TG (Mashek et al., 2002), indicating that PUFA show potential to moderate the development of hepatic lipidosis. Moreover, linolenic acid appeared to be one of the most beneficial FA because its addition to media resulted in decreased triacylglycerol concentrations and one of the highest rates of gluconeogenesis compared with other longchain FA (Mashek and Grummer, 2003). Feeding a source of n-3 FA before calving could then contribute to decreasing lipid accumulation in the liver and prevent fatty liver in the transition dairy cows. Therefore, the objectives of the present experiment were to determine the effects of feeding flaxseed, a rich source of n-3 FA, on liver concentrations of TG, glycogen, and total lipids, liver and blood profiles of FA, and plasma concentrations of NEFA, BHBA, FA, and glucose. Energy Booster, a source of saturated and rumen inert lipids, was compared with flaxseed to determine the effects of dietary lipids with different profiles of fatty acids.

\section{MATERIALS AND METHODS}

The experiment was conducted at the Dairy and Swine Research and Development Centre (Quebec, Canada) from August 2002 to January 2003 using 18 multiparous and 15 primiparous dry Holstein cows averaging $687 \mathrm{~kg}$ of $\mathrm{BW}(\mathrm{SE}=13 \mathrm{~kg})$. Cows were cared for in accordance with the guidelines of the Canadian Council on Animal Care (CCAC, 1993). Cows were stratified by groups of 3 within parity (primiparous or multiparous) for similar expected calving dates, and within group, randomly assigned in wk 6 prepartum to 1 of 3 TMR formulated to meet requirements of dry cows (Table 1): control with no added lipids (CO), unsaturated lipids supplied as $3.3 \%$ whole flaxseed (FL) rich in $\mathrm{n}$ $3 \mathrm{FA}$, and saturated lipids supplied via 1.7\% Energy Booster (EB; Milk Specialties Co., Dundee, IL). After calving, diets $\mathrm{CO}, \mathrm{EB}$, and FL were formulated to meet requirements for cows that averaged $635 \mathrm{~kg}$ of $\mathrm{BW}$ and produced $40 \mathrm{~kg} / \mathrm{d}$ of milk with $3.90 \%$ fat (NRC, 2001;
Table 1. Ingredient and chemical composition of the precalving experimental diets ${ }^{1,2}$

\begin{tabular}{|c|c|c|c|c|}
\hline Item & $\mathrm{CO}$ & FL & EB & $\mathrm{SE}$ \\
\hline \multicolumn{5}{|l|}{ Ingredient, $\%$ of DM } \\
\hline Grass silage & 43.8 & 45.7 & 47.5 & \\
\hline Corn silage & 30.5 & 32.7 & 34.3 & \\
\hline Hay & 7.9 & 8.0 & 7.8 & \\
\hline Whole flaxseed $^{3}$ & 0 & 3.3 & 0 & \\
\hline Protein supplement ${ }^{4}$ & 0 & 0 & 1.5 & \\
\hline Soybean meal (49\% CP) & 1.6 & 0 & 0 & \\
\hline Energy Booster ${ }^{5}$ & 0 & 0 & 1.7 & \\
\hline High-moisture corn & 14.9 & 9.0 & 5.9 & \\
\hline Mineral and vitamin premix ${ }^{6}$ & 1.3 & 1.3 & 1.3 & \\
\hline \multicolumn{5}{|l|}{ Chemical } \\
\hline $\mathrm{DM}, \%$ & 40.7 & 40.4 & 38.9 & 1. \\
\hline $\mathrm{CP}, \%$ of $\mathrm{DM}$ & 15.6 & 15.5 & 15.2 & 0.2 \\
\hline Ether extract, \% of DM & $2.7^{\mathrm{b}}$ & $4.2^{\mathrm{a}}$ & $4.1^{\mathrm{a}}$ & 0.2 \\
\hline $\mathrm{NDF}, \%$ of DM & 40.1 & 38.8 & 40.7 & 1.0 \\
\hline $\mathrm{ADF}, \%$ of $\mathrm{DM}$ & 24.2 & 24.4 & 24.5 & 0.9 \\
\hline $\mathrm{NE}_{\mathrm{L}}, \mathrm{Mcal} / \mathrm{kg}^{7}$ & 1.48 & 1.48 & 1.51 & \\
\hline \multicolumn{5}{|l|}{ Fatty acids, $\%$ of total } \\
\hline $\mathrm{C} 12: 0$ & 1.0 & 0.9 & 1.1 & 0.1 \\
\hline C14:0 & $0.9^{\mathrm{b}}$ & $1.0^{\mathrm{b}}$ & $2.6^{\mathrm{a}}$ & 0.2 \\
\hline C16:0 & $17.9^{\mathrm{b}}$ & $15.0^{\mathrm{c}}$ & $25.9^{\mathrm{a}}$ & 1.3 \\
\hline $\mathrm{C} 16: 1$ & $0.5^{\mathrm{b}}$ & $0.1^{\mathrm{c}}$ & $0.7^{\mathrm{a}}$ & 0.1 \\
\hline C18:0 & $2.4^{\mathrm{b}}$ & $3.1^{\mathrm{b}}$ & $19.0^{\mathrm{a}}$ & 2.1 \\
\hline C18:1 cis-11 & 0.9 & 1.0 & 1.1 & 0.1 \\
\hline C18:1n-9 cis & $14.3^{\mathrm{a}}$ & $14.5^{\mathrm{a}}$ & $11.1^{\mathrm{b}}$ & 0.4 \\
\hline C18:1n-9 trans & $0^{\mathrm{b}}$ & $0^{\mathrm{b}}$ & $0.9^{\mathrm{a}}$ & 0.1 \\
\hline $\mathrm{C} 18: 2 \mathrm{n}-6$ cis & $38.8^{\mathrm{a}}$ & $31.3^{b}$ & $22.8^{\mathrm{c}}$ & 1.8 \\
\hline C18:3n-3 & $23.3^{\mathrm{b}}$ & $33.1^{\mathrm{a}}$ & $14.8^{\mathrm{c}}$ & 2.1 \\
\hline
\end{tabular}

${ }^{\mathrm{a}-c}$ Means within rows with different superscripts differ $(P<0.05)$.

${ }^{1} \mathrm{CO}=$ supplement with no fat; $\mathrm{FL}=$ supplement with whole flaxseed; and EB = supplement with energy booster.

${ }^{2}$ Mean of 5 monthly samples prepared by compositing weekly samples.

${ }^{3}$ Contained 5.2\% C16:0, 3.4\% C18:0, 18.5\% C18:1, $16.1 \%$ C18:2, and $56.8 \% \mathrm{C} 18: 3$ (\% of total fatty acids).

${ }^{4}$ Contained $52.6 \% \mathrm{CP}, 8.5 \% \mathrm{ADF}$, and $13.5 \% \mathrm{NDF}$. Supplement contained $25 \%$ corn gluten meal, $20 \%$ soybean meal, $20 \%$ wheat distillers grain, $20 \%$ canola meal, and $15 \%$ corn distillers grains.

${ }^{5}$ Milk Specialities Co., Dundee, IL. Contained, as a percentage of total fatty acids, $4.0 \% \mathrm{C} 14: 0,34.8 \% \mathrm{C} 16: 0,0.9 \% \mathrm{C} 16: 1,49.0 \% \mathrm{C} 18: 0$, $1.9 \% \mathrm{C} 18: 1 \mathrm{n}-9$ trans, $6.7 \% \mathrm{C} 18: 1 \mathrm{n}-9 \mathrm{cis}, 0.9 \% \mathrm{C} 18: 1 \mathrm{cis}-11$, and $1.8 \%$ C18:2n-6 cis.

${ }^{6}$ Contained $3.0 \% \mathrm{Ca}, 12.0 \% \mathrm{P}, 12.0 \% \mathrm{Mg}, 2.4 \% \mathrm{Na}, 2.0 \% \mathrm{~S}, 40 \mathrm{mg} /$ $\mathrm{kg}$ of Se, $7,700 \mathrm{mg} / \mathrm{kg}$ of Zn, $200 \mathrm{mg} / \mathrm{kg}$ of I, $120 \mathrm{mg} / \mathrm{kg}$ of Co, 6,500 $\mathrm{mg} / \mathrm{kg}$ of Mn, $1,600 \mathrm{mg} / \mathrm{kg}$ of Cu, $4450 \mathrm{mg} / \mathrm{kg}$ of Fe, $800,000 \mathrm{IU} / \mathrm{kg}$ of vitamin A, 245,000 IU/kg of vitamin $\mathrm{D}$, and $7,500 \mathrm{IU} / \mathrm{kg}$ of vitamin E.

${ }^{7}$ Calculated using published values (NRC, 2001).

Table 2). On a DM basis, postpartum diet EB contained 3.5\% Energy Booster, and diet FL contained 11.0\% whole flaxseed; both diets had similar ether extract concentrations but fat was supplemented at different concentrations in precalving and postcalving diets. All diets were isonitrogenous and isoenergetic. The experiment was carried out from wk 6 before parturition to d 28 of lactation. Cows were housed in tie stalls and milked twice daily at 0545 and $1645 \mathrm{~h}$. Milk production was recorded at every milking. 
Table 2. Ingredient and chemical composition of the postcalving experimental diets ${ }^{1,2}$

\begin{tabular}{|c|c|c|c|c|}
\hline Item & $\mathrm{CO}$ & FL & $\mathrm{EB}$ & $\mathrm{SE}$ \\
\hline \multicolumn{5}{|l|}{ Ingredient, \% of DM } \\
\hline Grass silage & 33.8 & 29.3 & 41.1 & \\
\hline Corn silage & 24.3 & 21.1 & 29.5 & \\
\hline Whole flaxseed ${ }^{3}$ & 0 & 11.0 & 0 & \\
\hline Protein supplement ${ }^{4}$ & 0 & 4.9 & 7.1 & \\
\hline Soybean meal ( $49 \% \mathrm{CP})$ & 3.3 & 0 & 0 & \\
\hline Energy Booster ${ }^{5}$ & 0 & 0 & 3.5 & \\
\hline High-moisture corn & 36.0 & 31.0 & 16.9 & \\
\hline Mineral and vitamin premix ${ }^{6}$ & 2.6 & 2.7 & 1.9 & \\
\hline \multicolumn{5}{|l|}{ Chemical } \\
\hline $\mathrm{DM}, \%$ & $49.1^{\mathrm{a}}$ & $51.9^{\mathrm{a}}$ & $43.5^{\mathrm{b}}$ & 1.5 \\
\hline $\mathrm{CP}, \%$ of $\mathrm{DM}$ & 16.5 & 16.4 & 16.8 & 0.2 \\
\hline Ether extract, \% of DM & $4.6^{\mathrm{b}}$ & $6.8^{\mathrm{a}}$ & $7.3^{\mathrm{a}}$ & 0.3 \\
\hline $\mathrm{NDF}, \%$ of DM & $33.5^{\mathrm{b}}$ & $33.4^{\mathrm{b}}$ & $39.4^{\mathrm{a}}$ & 1.0 \\
\hline $\mathrm{ADF}, \%$ of $\mathrm{DM}$ & $18.5^{\mathrm{b}}$ & $18.2^{\mathrm{b}}$ & $23.2^{\mathrm{a}}$ & 1.0 \\
\hline $\mathrm{NE}_{\mathrm{L}}, \mathrm{Mcal} / \mathrm{kg}^{7}$ & 1.64 & 1.63 & 1.67 & \\
\hline \multicolumn{5}{|l|}{ Fatty acids, $\%$ of total } \\
\hline $\mathrm{C} 12: 0$ & $0.5^{\mathrm{ab}}$ & $0^{\mathrm{b}}$ & $0.8^{\mathrm{a}}$ & 0.1 \\
\hline C14:0 & $0.7^{\mathrm{b}}$ & $0.1^{\mathrm{c}}$ & $2.7^{\mathrm{a}}$ & 0.3 \\
\hline C16:0 & $16.7^{\mathrm{b}}$ & $11.5^{\mathrm{c}}$ & $27.3^{\mathrm{a}}$ & 2.1 \\
\hline C16:1 & $0.1^{\mathrm{b}}$ & $0^{\mathrm{b}}$ & $0.7^{\mathrm{a}}$ & 0.1 \\
\hline C18:0 & $2.5^{\mathrm{b}}$ & $2.8^{\mathrm{b}}$ & $23.4^{\mathrm{a}}$ & 2.7 \\
\hline C18: 1 cis -11 & $1.3^{\mathrm{a}}$ & $0.7^{b}$ & $1.0^{\mathrm{ab}}$ & 0.1 \\
\hline C18:1n-9 cis & $19.3^{\mathrm{a}}$ & $17.8^{\mathrm{ab}}$ & $11.3^{\mathrm{b}}$ & 1.4 \\
\hline C18:1n-9 trans & $0^{\mathrm{b}}$ & $0^{\mathrm{b}}$ & $1.0^{\mathrm{a}}$ & 0.1 \\
\hline C18:2n-6 cis & $46.6^{\mathrm{a}}$ & $35.1^{\mathrm{b}}$ & $21.5^{\mathrm{b}}$ & 3.6 \\
\hline C18:3 & $12.3^{\mathrm{b}}$ & $32.0^{\mathrm{a}}$ & $10.3^{\mathrm{b}}$ & 2.7 \\
\hline
\end{tabular}

${ }^{\mathrm{a}-\mathrm{c}}$ Means within rows with different superscripts differ $(P<0.05)$.

${ }^{1} \mathrm{CO}=$ supplement with no fat; FL = supplement with whole flaxseed; and EB = supplement with energy booster.

${ }^{2}$ Mean of 5 monthly samples that were prepared by compositing weekly samples.

${ }^{3}$ Contained $5.2 \%$ C16:0, 3.4\% C18:0, 18.5\% C18:1, $16.1 \%$ C18:2, and $56.8 \% \mathrm{C} 18: 3$ (\% of total fatty acids).

${ }^{4}$ Contained $52.6 \%$ CP, 8.5\% ADF, and 13.5\% NDF. Supplement contained $25 \%$ corn gluten meal, $20 \%$ soybean meal, $20 \%$ wheat distillers grains, $20 \%$ canola meal, and $15 \%$ corn distillers grains.

${ }^{5}$ Milk Specialities Co., Dundee, IL.

${ }^{6}$ Contained $8.8 \% \mathrm{Ca}, 4.5 \% \mathrm{P}, 3.6 \% \mathrm{Mg}, 14.4 \% \mathrm{Na}, 2.2 \% \mathrm{~S}, 18 \mathrm{mg} /$ $\mathrm{kg}$ of Se, $3,200 \mathrm{mg} / \mathrm{kg}$ of Zn, $70 \mathrm{mg} / \mathrm{kg}$ of I, $35 . \mathrm{mg} / \mathrm{kg}$ of Co, 2,200 mg/ $\mathrm{kg}$ of $\mathrm{Mn}, 530 \mathrm{mg} / \mathrm{kg}$ of $\mathrm{Cu}, 2,270 \mathrm{mg} / \mathrm{kg}$ of $\mathrm{Fe}, 400,000 \mathrm{IU} / \mathrm{kg}$ of vitamin A, 70,000 IU/kg of vitamin D, and 1,820 IU/kg of vitamin $\mathrm{E}$.

${ }^{7}$ Calculated using published values (NRC, 2001).

Milk samples were obtained weekly from each cow for 2 consecutive milkings and were analyzed separately to determine milk composition. Milk samples were stored at $4^{\circ} \mathrm{C}$ with a preservative (bronopol-B2) until analyzed for fat, protein, lactose, and SCC; milk samples without preservative were frozen at $-20^{\circ} \mathrm{C}$ until analyzed for milk FA profile. Body weight of cows was determined at $-42,-35,-28,-21,-14$, and $-7 \mathrm{~d}$ relative to expected parturition and weekly after parturition. Cows were fed individually twice a day at 0600 and $1400 \mathrm{~h}$ for $10 \%$ refusals, and feed consumption was recorded daily. Samples of TMR were taken weekly, frozen, and composited on a 4 -wk basis. Composited samples were mixed thoroughly and subsampled for chemical analyses. Energy balance postpartum was calculated weekly as the difference between energy consumed and required, where $\mathrm{NE}_{\mathrm{L}}$ required postpartum $=\mathrm{NE}_{\mathrm{L}}$ for maintenance plus $\mathrm{NE}_{\mathrm{L}}$ for milk. Energy required for maintenance $(\mathrm{Mcal} / \mathrm{d})=0.08 \times \mathrm{kg}$ of $\mathrm{BW}^{0.75}$, and for lactation $=\mathrm{kg}$ of milk $\times[(0.0929 \times$ milk fat \% $)+(0.0547$ $\times$ milk protein \%) + 0.192] $(\mathrm{NRC}, 2001)$.

Blood was collected on wk 6, 4, 2, and 1 prepartum, at calving, and on wk 1,2 , and 4 postpartum $1 \mathrm{~h}$ postfeeding. Blood was withdrawn from the jugular vein into Vacutainer tubes (Becton, Dickinson and Co., Rutherford, NJ) containing EDTA for NEFA, urea, and FA analyses and into Vacutainer tubes containing heparin for BHBA and glucose analyses. Tubes were immediately placed on ice and centrifuged within $1 \mathrm{~h}$ at $4^{\circ} \mathrm{C}$ for $30 \mathrm{~min}$ at $3,000 \times \mathrm{g}$. The plasma was separated and frozen at -80 and $-20^{\circ} \mathrm{C}$, respectively, for subsequent analysis of individual FA and other components.

Samples of liver were collected from each cow on wk 6 and 2 prepartum, and on wk 2 and 4 postpartum. Liver samples were obtained via puncture biopsy under local anesthesia through an incision on the right side of the cow at the 10th intercostal, where it crossed a line from midhumerus to tuber coxae. An incision approximately $1 \mathrm{~cm}$ long was made, and about $2.5 \mathrm{~g}$ of liver tissue was collected at each biopsy. Upon collection, the liver samples were rinsed with saline to remove excess blood and immediately placed into liquid nitrogen. Samples were stored at $-80^{\circ} \mathrm{C}$ until analyzed for FA profile and concentrations of TG, glycogen, and total lipids.

\section{Chemical Analysis}

Dry matter of TMR was determined by drying at $105^{\circ} \mathrm{C}$ for $48 \mathrm{~h}$ (AOAC, 1990; method 930.15). Total feed $\mathrm{N}$ determination was done by combustion assay (Leco model FP-428 Nitrogen Determinator, Leco, St. Joseph, MI) following method 990.03 of AOAC (1990). Neutral and acid detergent fiber components were measured according to the nonsequential procedures of Van Soest et al. (1991). Plasma samples were analyzed for NEFA (NEFA C-kit, Wako Chemicals USA, Richmond, VA) as described by McCutcheon and Bauman (1986), glucose (kit 14448668, Roche/Hitachi, Indianapolis, IN; Trinder, 1969), BHBA (Williamson et al., 1962; kit 310A, Sigma Diagnostic Inc., St. Louis, MO), and urea (kit 2050, Stanbio, Boerne, TX) concentrations. The Berthelot reaction was used to measure plasma urea (Tabacco et al., 1979), but phenol was replaced by salicylic acid (Stanbio). All CV assays were below 5\%. Nitrogen, fat, and lactose concentrations and SCC in milk were determined by infrared spectroscopy (Bentley 2000, Bentley Instrument Inc., Chaska, MN; AOAC, 1990). Ether extraction in diets was conducted with a Soxlec 
system HT6 apparatus (Tecator, Fisher Scientific, Montreal, Canada) according to method 920.39 (AOAC, 1990).

Plasma lipids (500 $\mu \mathrm{L}$ of plasma) were extracted according to the procedures outlined by Delbecchi et al. (2001), and preparation of plasma FA methyl esters was carried out as described by Park and Goins (1994). Total lipids in milk and liver were extracted as described by Delbecchi et al. (2001), and FA were methylated according to the method described by Chouinard et al. (1997) and in situ transesterification was performed on feed ingredients according to Park and Goins (1994). Fatty acid methyl ester profiles were measured by GLC on a Hewlett-Packard 6890 chromatograph (Hewlett-Packard Ltée, Montreal, Canada) with a G1315A autosampler equipped with a flame-ionization detector and a split-splitless injector as described by Delbecchi et al. (2001). Frozen liver ( $80 \mathrm{mg}$ ) was homogenized in PBS and a portion was used to determine glycogen according to the modified procedure of Andersen et al. (2002) using a colorimetric method (kit 1060, Stanbio). Liver was analyzed for concentrations of total lipids and TG using methodology described in Douglas et al. (2004).

\section{Statistical Analysis}

Measurements of DMI and milk yield were reduced to weekly means before statistical analysis. Data were analyzed as repeated measures using the PROC MIXED procedure of SAS (SAS Institute, 2000). The model included the fixed effects of treatment, parity (primiparous or multiparous), week, treatment by week interaction, treatment by parity interaction, the random effect of cows nested within treatment, treatment by parity by week interaction, and the residual error. Data on DMI and BW were analyzed separately for the prepartum and postpartum periods. Data on blood concentrations of glucose, BHBA, and urea N, blood and liver FA profiles, and liver total lipids, glycogen, and TG concentrations were analyzed separately for multiparous and primiparous cows. When differences $(P<0.10)$ due to interactions or dietary treatments were detected, means separation was conducted using the Tukey test of SAS (SAS Institute, 2000). Differential temporal responses to dietary treatments were further examined using the SLICE option of the MIXED procedure. Significance was declared at $P \leq 0.05$ and a trend at $P \leq 0.10$ unless otherwise stated. Residuals were plotted to detect assumptions of normality and homogeneity of variance. Data on SCC were transformed $(\log )$ because of lack of variance homogeneity.
Table 3. Postpartum diseases of Holstein cows fed supplements based on no fat (CO), whole flaxseed (FL), or energy booster (EB)

\begin{tabular}{lccc}
\hline & \multicolumn{3}{c}{ Treatment } \\
\cline { 2 - 4 } Disease & CO $(\mathrm{n}=11)$ & FL $(\mathrm{n}=11)$ & EB $(\mathrm{n}=11)$ \\
\hline Milk fever & 4 & 1 & 0 \\
Ketosis & 1 & 1 & 3 \\
Mastitis & 2 & 0 & 2 \\
Diarrhea & 1 & 0 & 1 \\
Udder edema & 0 & 1 & 0 \\
Unexplained & 1 & 0 & 0 \\
\hline
\end{tabular}

\section{RESULTS}

Chemical composition of precalving (Table 1) and postcalving (Table 2) diets was generally similar among treatments. As planned, ether extract concentrations were higher for both diets containing fat supplements but there was no difference between FL and EB diets. The actual calving dates ranged from -7 to +10 compared with the predicted dates and they were similar among treatments.

The overall frequency of postpartum diseases (Table 3 ) was high, especially for milk fever and ketosis. Moreover, the number of diseases was numerically lower for cows fed FL $(\mathrm{n}=3)$ compared with those fed CO ( $\mathrm{n}=$ 9) and EB $(n=6)$.

Average DMI prepartum was significantly greater for multiparous than primiparous cows (14.5 vs. $11.2 \mathrm{~kg} /$ $\mathrm{d}$; data not shown) and DMI was similar over time before calving (Figure 1). On average, DMI before calving, expressed in kilograms per day or as a percentage of BW, was significantly lower for cows fed EB compared with those fed CO, and there was no difference between cows fed FL and those fed either CO or EB (Table 4). There was no interaction between parity and treatment on DMI before calving. There was no difference in BW determined 6 or 1 wk before calving although $\mathrm{BW}$ gain

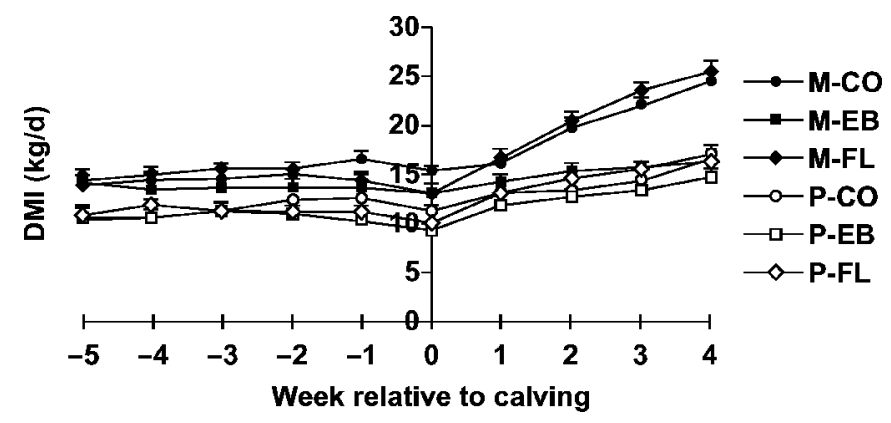

Figure 1. Dry matter intake of multiparous (M) and primiparous (P) Holstein cows fed supplements based on no fat (CO), whole flaxseed (FL), or energy booster (EB). Effects of parity and treatment were significant before calving $(P<0.01)$. There was a significant interaction between parity and treatment after calving $(P<0.01)$. 
Table 4. Feed intake, BW, and milk production of Holstein cows fed supplements based on no fat (CO), whole flaxseed (FL), or energy booster $(\mathrm{EB})^{1}$

\begin{tabular}{lcccc}
\hline & \multicolumn{3}{c}{ Treatment } & \\
\cline { 2 - 4 } & CO & FL & EB & SE \\
\hline Precalving DMI, kg/d & $13.4^{\mathrm{a}}$ & $12.9^{\mathrm{ab}}$ & $12.1^{\mathrm{b}}$ & 0.36 \\
Precalving DMI, \% of BW & $1.99^{\mathrm{a}}$ & $1.89^{\mathrm{ab}}$ & $1.75^{\mathrm{b}}$ & 0.05 \\
BW, kg & & & & \\
6 wk before calving & 644 & 655 & 668 & 19 \\
1 wk before calving & 716 & 717 & 717 & 16 \\
Precalving BW change, g/d & $72^{\mathrm{a}}$ & $62^{\mathrm{ab}}$ & $49^{\mathrm{b}}$ & 7 \\
Postcalving DMI, kg/d & $18.1^{\mathrm{a}}$ & $18.7^{\mathrm{a}}$ & $14.6^{\mathrm{b}}$ & 0.7 \\
Postcalving DMI, \% of BW & $2.81^{\mathrm{a}}$ & $2.80^{\mathrm{a}}$ & $2.35^{\mathrm{b}}$ & 0.09 \\
Milk yield, kg/d & $33.3^{\mathrm{a}}$ & $32.8^{\mathrm{a}}$ & $29.1^{\mathrm{b}}$ & 1.1 \\
Milk composition, \% & & & & \\
Protein & 3.29 & 3.27 & 3.26 & 0.07 \\
Fat & $3.99^{\mathrm{ab}}$ & $3.92^{\mathrm{b}}$ & $4.30^{\mathrm{a}}$ & 0.13 \\
Lactose & $4.60^{\mathrm{ab}}$ & $4.64^{\mathrm{a}}$ & $4.50^{\mathrm{b}}$ & 0.04 \\
SCS & $4.16^{\mathrm{ab}}$ & $3.79^{\mathrm{b}}$ & $4.64^{\mathrm{a}}$ & 0.30 \\
4\% FCM, kg/d & 31.8 & 31.1 & 30.1 & 1.4 \\
Milk yield, kg/d & & & & \\
Protein & 1.01 & 1.01 & 0.92 & 0.04 \\
Fat & 1.29 & 1.23 & 1.24 & 0.06 \\
Lactose & $1.46^{\mathrm{a}}$ & $1.47^{\mathrm{a}}$ & $1.30^{\mathrm{b}}$ & 0.05 \\
BW, kg & & & & \\
1 wk after calving & 656 & 661 & 652 & 16 \\
4 wk after calving & 635 & 638 & 624 & 15 \\
BW change, g/d & -22 & -22 & -28 & 8 \\
\hline
\end{tabular}

${ }^{\mathrm{a}, \mathrm{b}}$ Means within rows with different superscripts differ $(P<0.05)$.

${ }^{1}$ Least squares means with pooled SE.

${ }^{2} P=0.07$.

${ }^{3}$ Somatic cell score $=\log _{10} \mathrm{SCC}$.

tended ( $P=0.07)$ to be lower for cows fed EB than for those fed CO, which may be a result of cows fed the former diet having the lowest DMI. Body condition score averaged 3.5 and 3.4 before and after calving, respectively, and treatment had no effect (data not shown).

After calving, there was a significant interaction between parity and treatment because of higher DMI for multiparous cows fed CO or FL and similar DMI among treatments for primiparous cows (Figure 1). On average, DMI increased more rapidly after calving for multiparous than primiparous cows (Figure 1), resulting in a significant interaction between parity and week for postcalving DMI.

Average daily milk yield (Table 4) was significantly lower for cows fed EB compared with those fed CO or FL. Multiparous cows had greater $(P<0.01)$ milk yield than primiparous cows $(31.0$ vs. $28.2 \mathrm{~kg} / \mathrm{d}$; data not shown). Multiparous and primiparous cows responded similarly to the 3 diets as shown by the lack of any interaction between parity and treatment. There was an interaction $(P<0.01)$ between week of lactation and treatment on milk yield (data not shown) as a result of a greater $(P<0.01)$ increase in milk production between wk 1 and 4 of lactation for cows fed FL $(18.1 \mathrm{~kg} / \mathrm{d})$ and
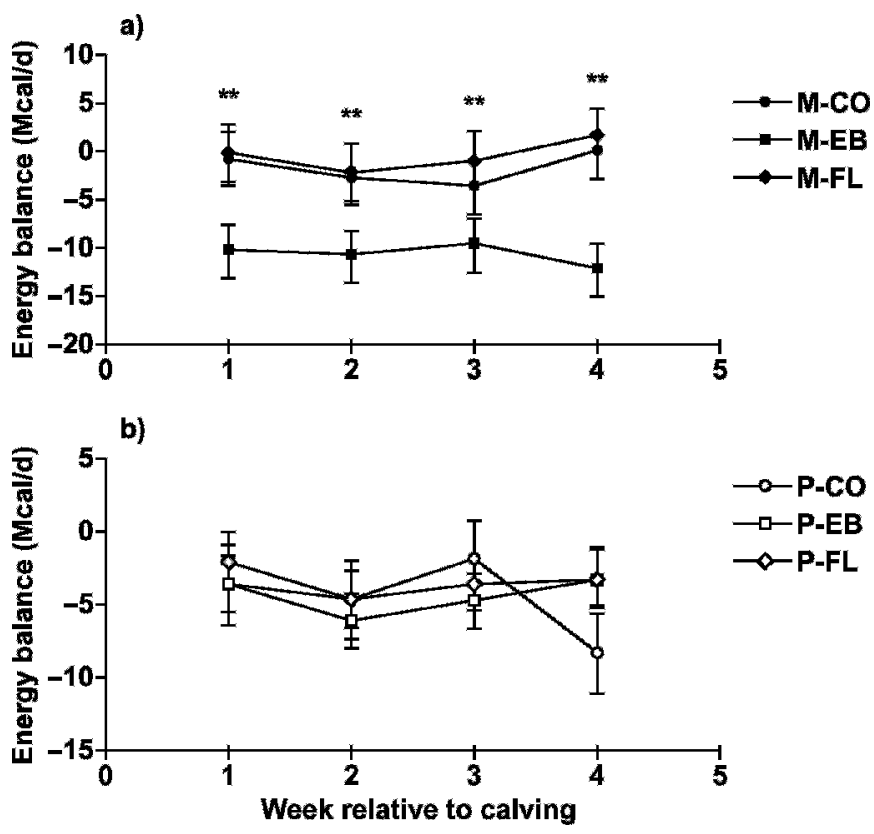

Figure 2. Energy balance of a) multiparous and b) primiparous Holstein cows fed supplements based on no fat (CO), whole flaxseed (FL), or energy booster (EB). Asterisks indicate significant treatment differences $(* * P<0.01)$.

those fed CO (14.3 kg/d) compared with those fed EB $(10.3 \mathrm{~kg} / \mathrm{d})$. Moreover, there was an interaction between parity and treatment on energy balance; multiparous cows fed EB had a significantly lower energy balance than those fed FL and CO (Figure 2a) and there was no treatment effect for primiparous cows (Figure $2 b$ ).

Milk protein concentration was similar among treatments (Table 4). On average, milk fat concentration was significantly higher for cows fed EB $(4.30 \%)$ than for those fed FL (3.92\%); cows fed $\mathrm{CO}(3.99 \%)$ had values similar to those of cows fed EB and FL. Average milk lactose concentration was significantly lower for cows fed EB (4.49\%) compared with those fed FL (4.64\%), and there was no difference between cows fed $\mathrm{CO}$ (4.60\%) and those fed EB or FL (Table 4). Cows fed FL had significantly lower SCS than those fed EB and cows fed CO had SCS similar to those of cows fed either FL or EB. Production of $4 \%$ FCM was similar among treatments. Milk yields of protein and fat were similar among treatments but yield of lactose was significantly higher for cows fed CO and FL than for those fed EB. Change in BW was similar among treatments (Table 4).

Data on relative percentages of milk FA were presented as a percentage of identified FA, which did not include the unknown relative percentages present in milk fat. Relative percentages of 10:0, 12:0, 14:0, cis- 6 18:2, and total PUFA in milk fat were similar for cows fed CO and FL and they were significantly higher than 
Table 5. Average milk fatty acid (FA) composition of Holstein cows fed supplements based on no fat (CO), whole flaxseed (FL), or energy booster $(\mathrm{EB})^{1}$

\begin{tabular}{lcccc}
\hline & \multicolumn{3}{c}{ Treatment } \\
\cline { 2 - 4 } FA & CO & FL & EB & SE \\
\cline { 2 - 3 } C10:0 & \multicolumn{4}{c}{ \% of total FA } \\
\cline { 2 - 3 } C12:0 & $4.1^{\mathrm{a}}$ & $3.3^{\mathrm{a}}$ & $1.6^{\mathrm{b}}$ & 0.3 \\
C14:0 & $4.3^{\mathrm{a}}$ & $3.4^{\mathrm{a}}$ & $1.7^{\mathrm{b}}$ & 0.3 \\
C14:1 & $12.6^{\mathrm{a}}$ & $11.0^{\mathrm{a}}$ & $7.3^{\mathrm{b}}$ & 0.6 \\
C16:0 & $0.9^{\mathrm{a}}$ & $0.8^{\mathrm{ab}}$ & $0.6^{\mathrm{b}}$ & 0.1 \\
C16:1 & $31.0^{\mathrm{a}}$ & $27.7^{\mathrm{b}}$ & $29.5^{\mathrm{a}}$ & 0.5 \\
C18:0 & 1.8 & 1.7 & 2.2 & 0.2 \\
Cis-11 18:1 & $14.0^{\mathrm{b}}$ & $16.9^{\mathrm{a}}$ & $17.1^{\mathrm{a}}$ & 0.7 \\
Cis-9 18:1 & $0.8^{\mathrm{b}}$ & 0.8 & 0.9 & 0.1 \\
Trans-18:1 & $24.4^{\mathrm{b}}$ & $27.3^{\mathrm{b}}$ & $34.2^{\mathrm{a}}$ & 1.4 \\
Cis-6 18:2 & $1.5^{\mathrm{b}}$ & $2.4^{\mathrm{a}}$ & $1.3^{\mathrm{b}}$ & 0.1 \\
Trans-6 18:2 & $3.2^{\mathrm{a}}$ & $3.0^{\mathrm{a}}$ & $2.4^{\mathrm{b}}$ & 0.1 \\
Cis-3 18:3 & 0.21 & 0.19 & 0.19 & 0.02 \\
Cis-6 20:3 & $0.73^{\mathrm{b}}$ & $1.09^{\mathrm{a}}$ & $0.73^{\mathrm{b}}$ & 0.04 \\
Cis-6 20:4 & $0.14^{\mathrm{a}}$ & $0.11^{\mathrm{ab}}$ & $0.06^{\mathrm{b}}$ & 0.02 \\
Cis-3 20:5 & $0.25^{\mathrm{a}}$ & $0.20^{\mathrm{ab}}$ & $0.18^{\mathrm{b}}$ & 0.02 \\
n-6/n-3 & $0.07^{\mathrm{ab}}$ & $0.11^{\mathrm{a}}$ & $0.04^{\mathrm{b}}$ & 0.02 \\
Polyunsaturated & $5.3^{\mathrm{a}}$ & $3.3^{\mathrm{c}}$ & $4.0^{\mathrm{b}}$ & 0.2 \\
\hline
\end{tabular}

${ }^{\mathrm{a}-c}$ Means within rows with different superscripts differ $(P<0.05)$.

${ }^{1}$ Least squares means with pooled SE.

those of cows fed EB (Table 5). On the other hand, cows fed EB had significantly higher relative percentage of cis-9 18:1 in milk fat than those fed the other diets. Relative percentages of 16:0 were significantly lower and those of trans-C18:1 and cis-3 18:3 were higher in milk fat of cows fed FL than in milk fat of those fed CO and EB. The n- 6 to n-3 FA ratio was significantly higher for cows fed CO compared with those fed EB and FL.

Dietary treatments had no effect on plasma lipid profile in primiparous cows (data not shown), except for C18:3 relative percentage, which was higher $(P<0.01)$ for primiparous cows fed FL (6.4\% of total lipids) compared with those fed EB (5.3\%) and CO (5.0\%). In multiparous cows, plasma $\mathrm{C} 16: 0$ relative percentages were generally higher for cows fed EB compared with those fed CO and FL (Figure 3a). Plasma relative percentage of C18:0 was significantly higher at calving for cows fed FL compared with those fed EB and CO (Figure $3 b)$. Plasma relative percentage of $\mathrm{C} 18: 1$ remained significantly higher after calving for cows fed EB compared with those fed CO and FL (Figure 3c), whereas the opposite was observed for relative percentage of C18:2 (Figure 3d). Plasma relative percentage of C18:3 remained generally higher for cows fed FL compared with those fed EB and CO. Relative percentages of C18:3 tended to be higher in wk 2 precalving and at calving ( $P=0.07$ and 0.06 , respectively) for cows fed FL and the difference was significant in wk 2 and 4 postcalving (Figure 3e).
For plasma glucose concentration, there was a significant interaction between treatment and time for multiparous cows; prepartum, there was no difference in blood glucose concentration among treatments, whereas from wk 1 postpartum, cows fed EB had lower concentrations compared with those fed $\mathrm{CO}$ and FL (Figure 4). Glucose concentrations of primiparous cows were not affected by treatment (data not shown). There was a significant interaction between treatment and time for NEFA concentrations of multiparous cows; there was no difference prepartum but multiparous cows fed EB had higher NEFA concentrations after calving than those fed $\mathrm{CO}$ and FL (Figure 5), whereas diets had no effect on blood NEFA concentrations of primiparous cows throughout the experiment (data not shown).

Both primiparous and multiparous cows showed a significant interaction between treatment and time for plasma BHBA concentrations. Multiparous cows fed EB had significantly greater BHBA concentrations after calving than those fed CO and FL (Figure 6a), whereas primiparous cows fed EB had greater BHBA concentrations only in wk 2 postcalving compared with cows fed either CO or FL (Figure 6b). Concentrations of BHBA in plasma of primiparous cows were similar among treatments for the other weeks. Blood urea N concentrations averaged $10.9,9.9$, and $9.1 \mathrm{mg} / 100 \mathrm{~mL}$; they were similar among treatments and there was no interaction between parity and treatment and between treatment and week (data not shown).

Primiparous cows had similar liver profiles of FA among treatments and over time, except in wk 4 prepartum when cows fed FL had lower $(P<0.01)$ relative percentages of all FA (data not shown). Liver C16:0 relative percentages in multiparous cows increased after calving (Figure 7a), whereas those of C18:0 decreased (Figure 7b) for all treatments. Relative percentages of liver C16:0 were significantly higher in wk 2 and 4 postpartum for multiparous cows fed EB compared with those fed CO and FL; conversely, those of C18:0 were significantly lower in wk 4 postpartum for cows fed EB compared with those fed CO and FL. Liver C18:1 relative percentages of multiparous cows (Figure 7c) increased after calving and were significantly higher in wk 4 for cows fed EB compared with those fed CO and FL. The opposite was observed for liver C18:2 relative percentages in which multiparous cows fed EB had lower C18:2 relative percentages in wk 4 after calving (Figure 7d). Relative percentages of C18:3 in the liver of multiparous cows decreased over time (Figure 7e). Mean liver C18:3 relative percentages were significantly higher for cows fed FL (1.89\% of total fatty acids) than for those fed EB (1.58\%) and CO (1.41\%). 
a)



c)

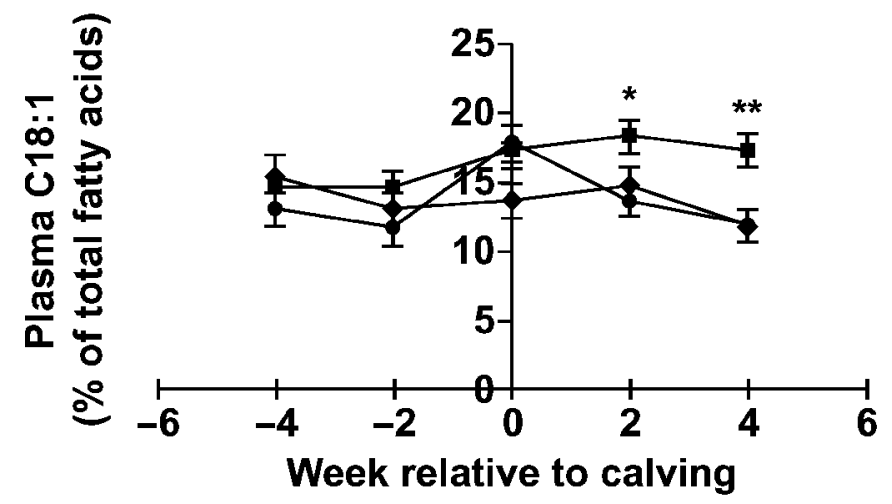

e)

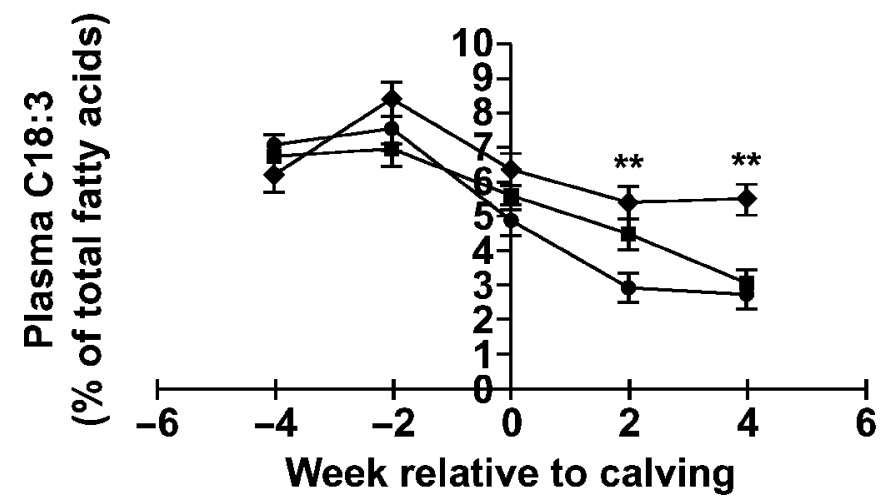

b)

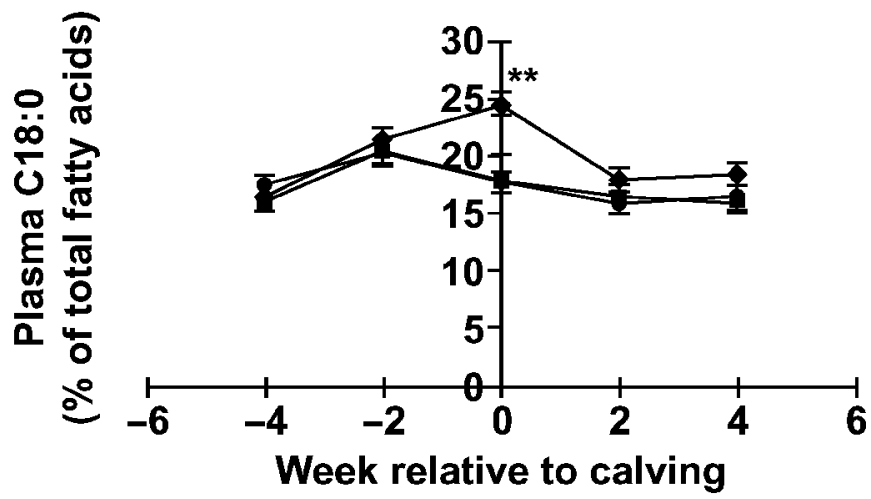

d)



Figure 3. Plasma relative percentages of a) C16:0, b) C18:0, c) C18:1, d) C18:2, and e) C18:3 in multiparous (M) Holstein cows fed supplements based on no fat (CO), whole flaxseed (FL), or energy booster (EB). Asterisks indicate significant treatment differences $(* P<$ $0.05 ; * * P<0.01)$

On average, primiparous cows had lower liver total lipids and TG concentrations than multiparous cows and there was no difference among treatments (data not shown). However, the change in liver total lipids and TG concentrations was significantly different among treatments for multiparous cows as indicated by the interaction between treatment and time. Multiparous cows fed EB had a greater increase postpartum in liver concentrations of total lipids (Figure 8a)and TG (Figure 8b) than those fed CO or FL, and those fed FL had liver TG concentrations significantly lower than cows fed $\mathrm{CO}$ or EB on wk 4 after calving. Liver glycogen concentration after calving was significantly higher for multiparous cows fed FL compared with those fed the other diets and multiparous cows fed EB had the lowest $(P<0.01)$ concentration (Figure 9a). Differences among 


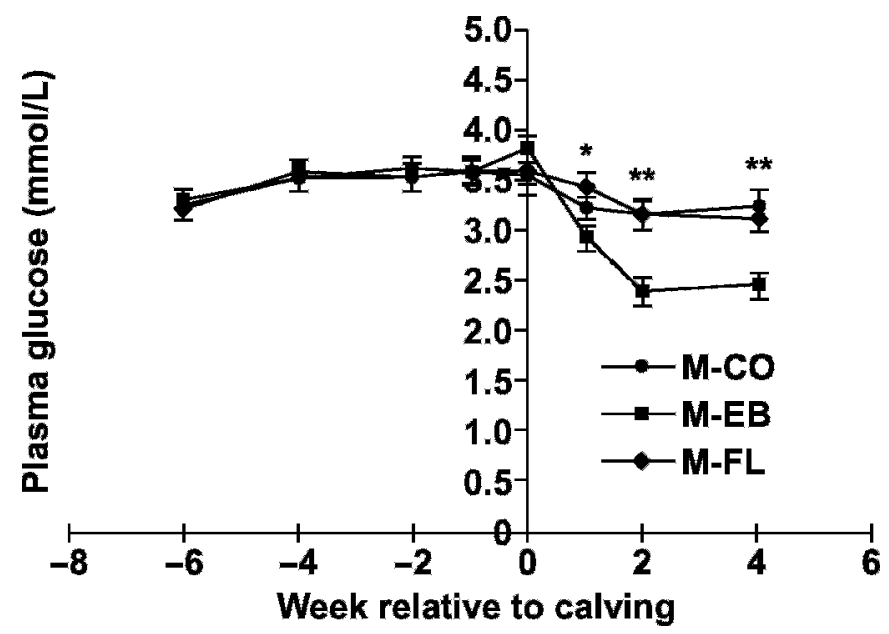

Figure 4. Plasma glucose concentration of multiparous Holstein cows fed supplements based on no fat (CO), whole flaxseed (FL), or energy booster (EB). Asterisks indicate significant treatment differences $(* P<0.05 ; * * P<0.01)$.

treatments for primiparous cows were seen only in wk 2 postpartum, when cows fed EB had significantly lower concentrations of liver glycogen compared with those fed $\mathrm{CO}$ and FL (Figure 9b).

The ratios of 16:1/16:0 and 18:1/18:0 FA in the liver were calculated because they are surrogate markers for stearoyl-CoA desaturase-1, which is a rate-limiting enzyme in the desaturation of 16:0 and 18:0 FA that is essential to TG formation (Wendel and Belury, 2006). The ratio of 16:1/16:0 in the liver was similar among treatments (data not shown) but the 18:1/18:0 FA ratio (Figure 10) was significantly lower for multiparous cows fed CO and FL in wk 4 postpartum compared with those

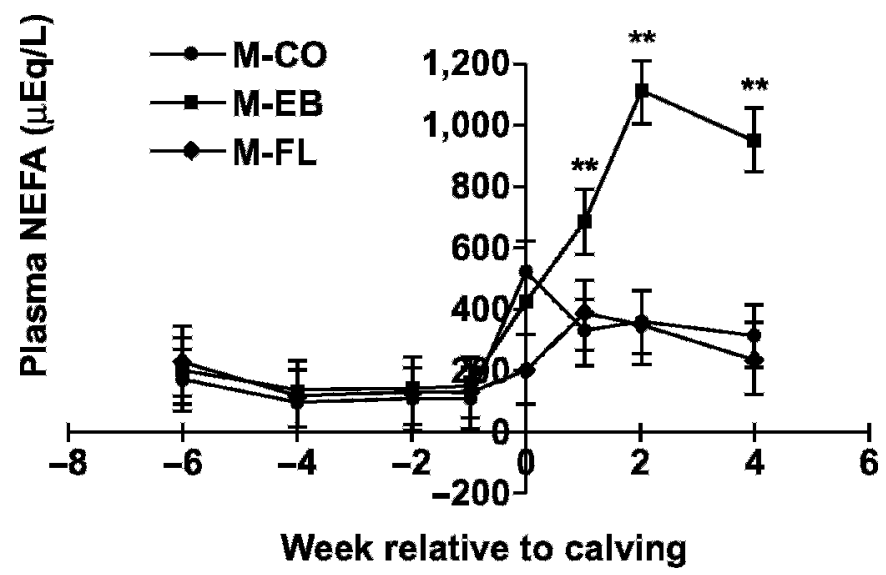

Figure 5. Plasma NEFA concentration of multiparous Holstein cows fed supplements based on no fat (CO), whole flaxseed (FL), or energy booster (EB). Asterisks indicate significant treatment differences $(* * P<0.01)$.
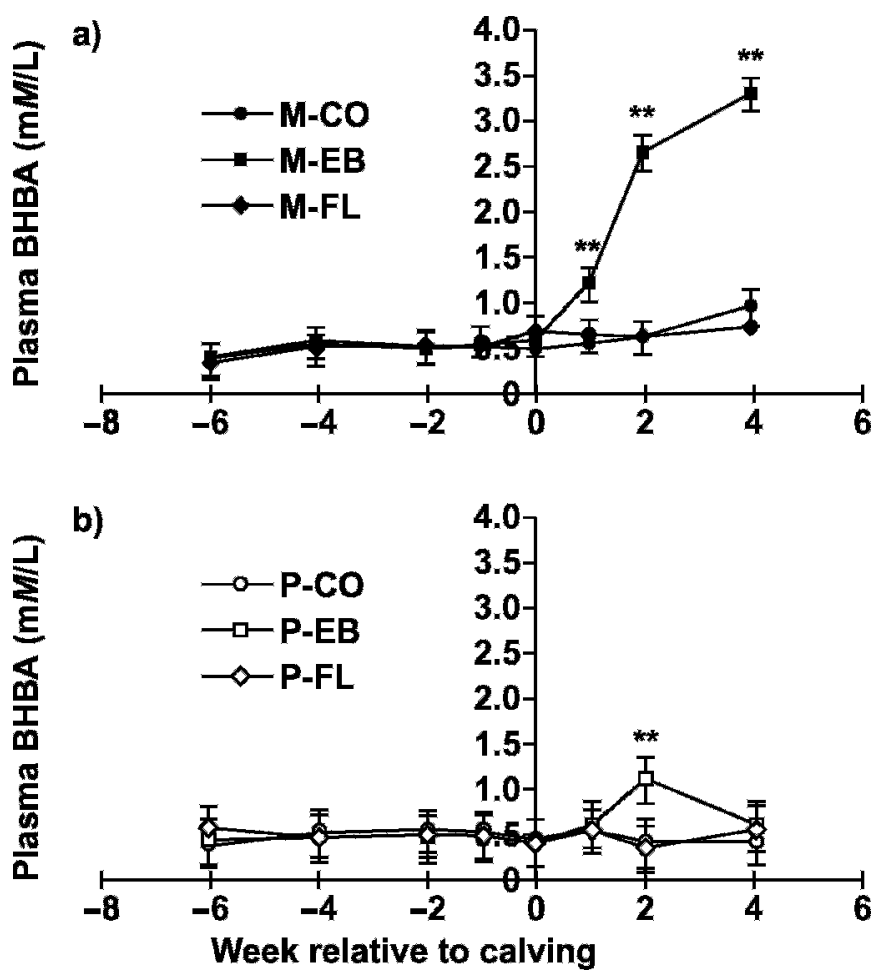

Figure 6. Plasma BHBA concentration of a) multiparous and b) primiparous Holstein cows fed supplements based on no fat (CO), whole flaxseed (FL), or energy booster (EB). Asterisks indicate significant treatment differences $(* * P<0.01)$.

fed EB. There was no difference among treatments for primiparous cows (data not shown).

\section{DISCUSSION}

Multiparous cows had greater DMI than primiparous cows, which is in agreement with the results of Hayirli et al. (2002). However, according to Hayirli and Grummer (2004), the prepartum DMI of heifers decreases with increasing dietary ether extract concentration, whereas the DMI of cows does not change. In the present experiment, a parity effect was not evident because neither primiparous nor multiparous cows showed a decrease in intake prepartum with increased dietary fat concentration. There is little information available to evaluate the effect of supplemental fat on DMI of cows before calving. One experiment carried out with ad libitum feeding (Douglas et al., 2004) reported no effect of prepartum fat supplementation on DMI of multiparous cows when using liquid fat (choice white grease with $46.2 \%$ C18:1).

Milk FA composition and the lowest n-6 to n-3 FA ratio in milk fat of cows fed FL were in agreement with those reported for cows fed 10\% whole flaxseed (Petit, 2002). Greater trans-18:1 relative percentage in milk 
a)

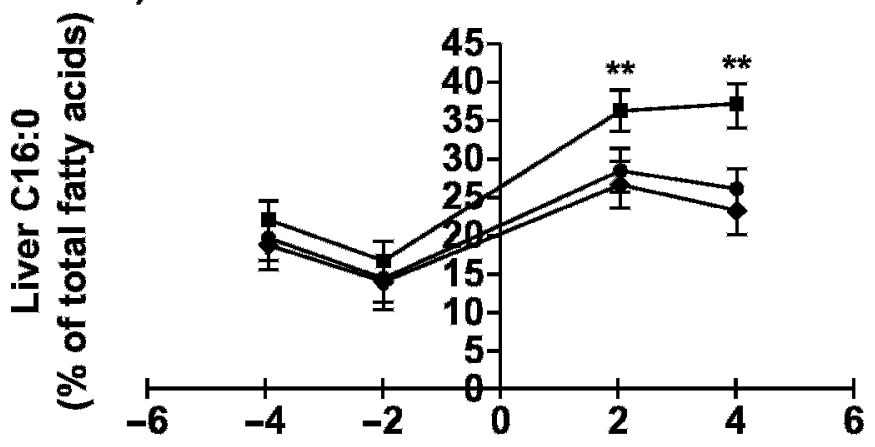

c)

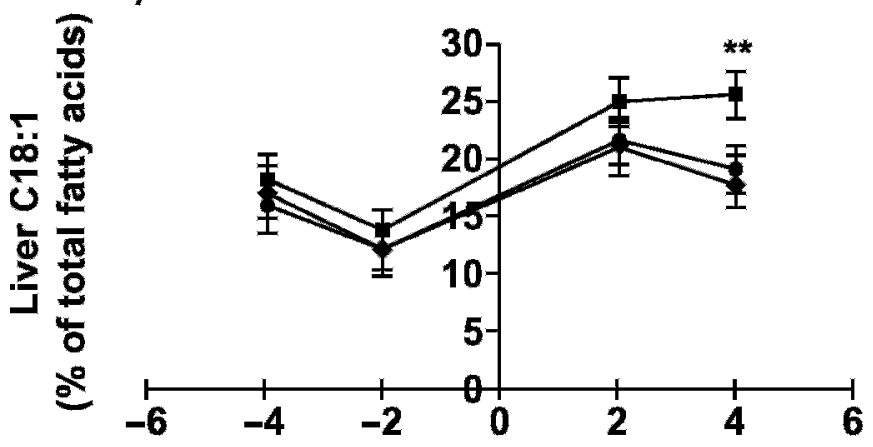

b)

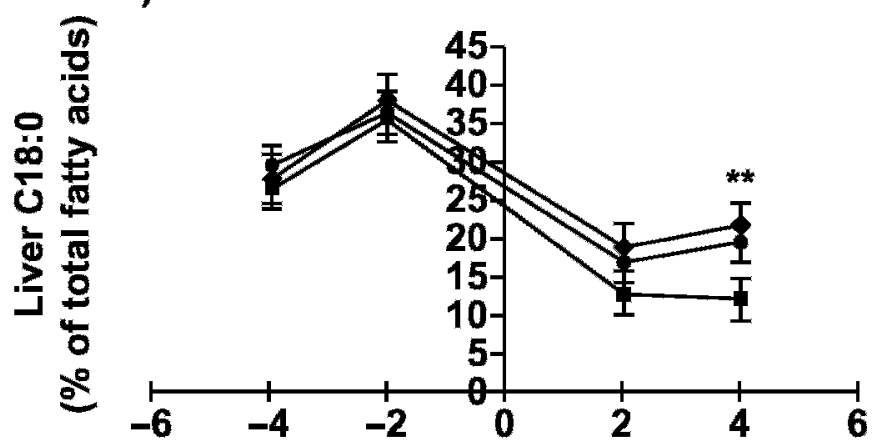

d)

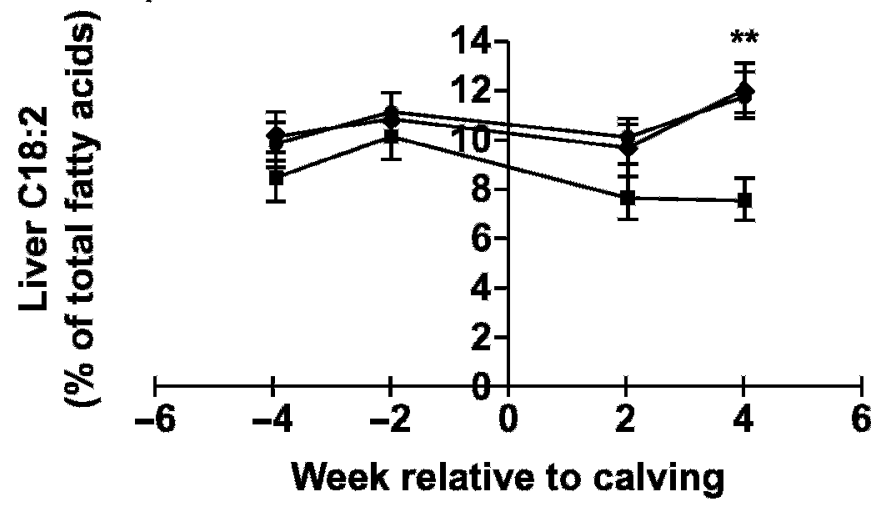

e)


Figure 7. Liver relative percentages of a) C16:0, b) C18:0, c) C18:1, d) C18:2, and e) C18:3 in multiparous (M) Holstein cows fed supplements based on no fat $(\mathrm{CO})$, whole flaxseed $(\mathrm{FL})$, or energy booster $(\mathrm{EB})$. Asterisks indicate significant treatment differences $(* P<$ $0.05 ; * * P<0.01)$.

fat has been reported previously when flaxseed was fed to dairy cows compared with when raw cracked soybeans were fed (Dhiman et al., 2000).

Concentrations of blood NEFA increased after calving, as is generally reported (Rukkwamsuk et al., 1999), but the increase was significantly more important for multiparous cows fed EB than for those fed CO and FL.
Plasma NEFA concentration is a reliable index of the magnitude of adipose fat mobilization (Bobe et al., 2004), indicating that multiparous cows fed EB may have had greater lipolysis of adipose tissue than those fed CO and FL. According to Mashek et al. (2005), infusion of tallow emulsion resulted in the highest concentrations of plasma NEFA and glucose, whereas the infu- 

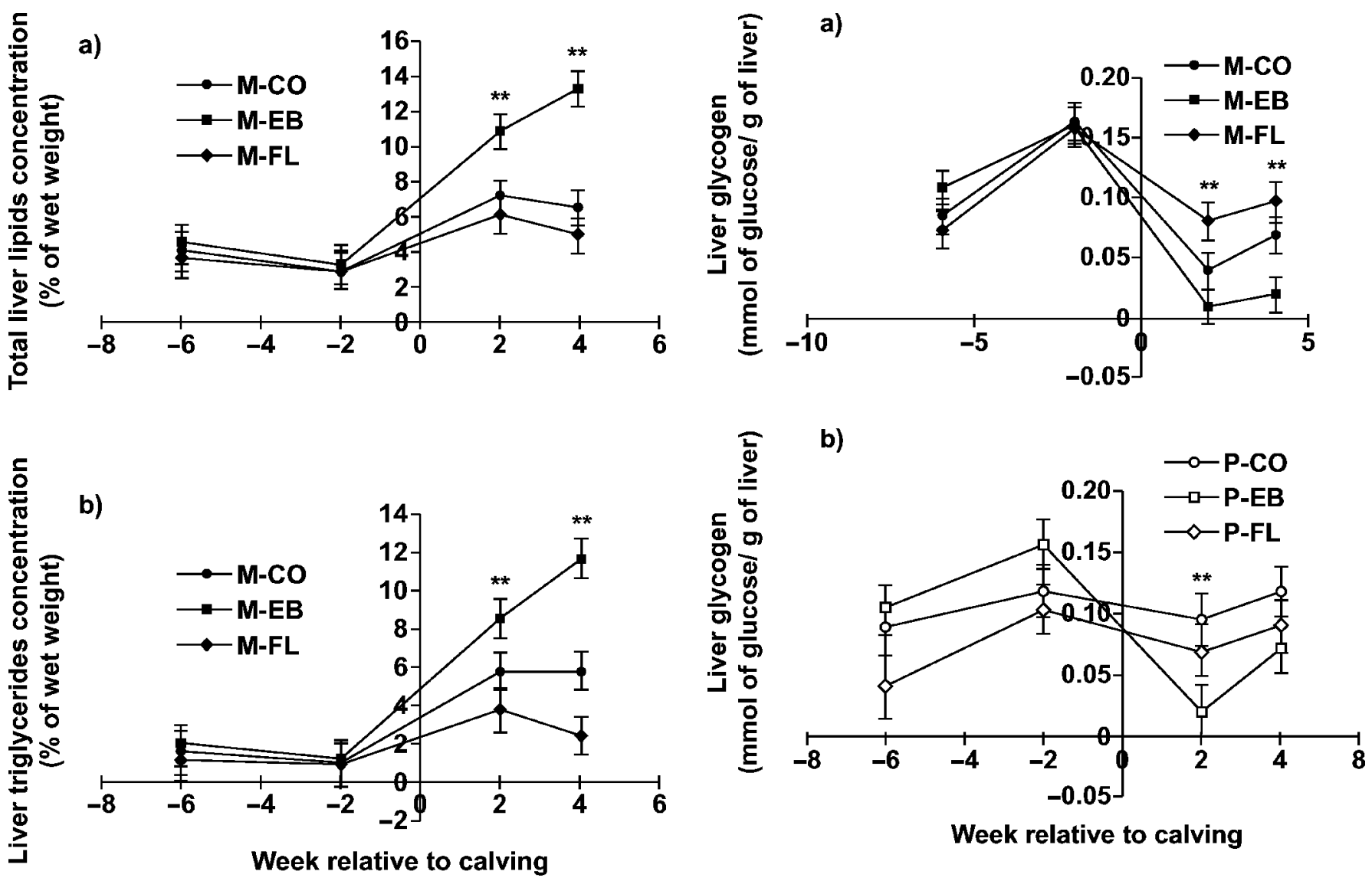

Figure 8. Liver concentrations of a) total lipids and b) triglycerides in multiparous (M) Holstein cows fed supplements based on no fat (CO), whole flaxseed (FL), or energy booster (EB). Asterisks indicate significant treatment differences $(* * P<0.01)$.

sion of linseed oil resulted in the lowest NEFA and BHBA concentrations. Moreover, Mashek et al. (2005) reported that liver TG content was lower for cows infused with linseed oil compared with those infused with tallow emulsion, which may suggest that cows receiving the linseed oil would be less susceptible to developing fatty liver. However, cows fed CO and FL did not mobilize adipose tissue as typically observed during the transition period. For example, values of NEFA concentrations for cows fed CO and FL barely reached $400 \mu \mathrm{Eq} /$ $\mathrm{L}$, which is lower than values usually reported in the literature. Moreover, the pattern of the energy balance and plasma concentrations of energetic variables (e.g., NEFA and BHBA) of cows fed CO did not follow the traditional and well-documented patterns of transition cows fed a diet without a fat supplement. Significant greater NEFA concentrations for multiparous than primiparous cows in the present experiment agree with previous reports (Vandehaar et al., 1999) and may indicate a greater susceptibility for hepatic lipidosis in mul-

Figure 9. Liver concentrations of glycogen of multiparous a) and primiparous b) Holstein cows fed supplements based on no fat (CO), whole flaxseed (FL), or energy booster (EB). Asterisks indicate significant treatment differences $(* * P<0.01)$.

tiparous than in primiparous cows. In the present experiment, average total liver lipid concentration in wk 2 and 4 postpartum of multiparous cows was almost 2

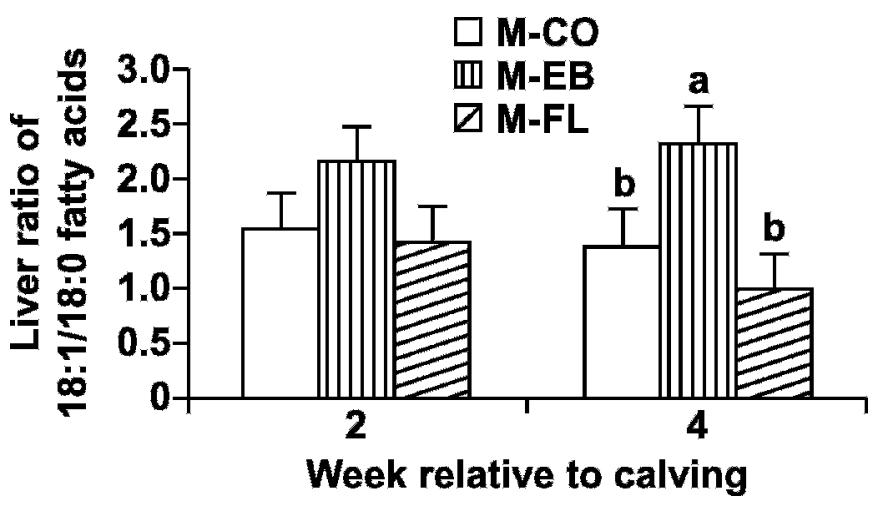

Figure 10. Liver ratio of 18:1/18:0 fatty acids in multiparous (M) Holstein cows fed supplements based on no fat (CO), whole flaxseed (FL), or energy booster (EB). ${ }^{\mathrm{a}, \mathrm{b}}$ Means within week relative to calving with different letters differ $(P<0.01)$. 
times higher than that of primiparous cows (8.1 vs. $4.5 \%$; data not shown), which is in agreement with the fact that older cows and high-producing cows are more likely to have fatty liver compared with younger, lower producing animals (Bobe et al., 2004).

Bertics et al. (1992) reported that DMI is inversely related to concentrations of NEFA and BHBA in plasma and liver TG. The data from the current study concur with this observation; multiparous cows fed EB had lower DMI and higher plasma concentrations of NEFA and BHBA and hepatic concentrations of TG and total lipids than those fed FL and CO. Low DMI prepartum contributes to increased hepatic lipidosis postpartum because of higher plasma NEFA and liver TG concentrations (Van Den Top et al., 1996) and the limited capacity of the dairy cow to export hepatic TG as very low density lipoprotein (Grummer, 1993). Additionally, elevated plasma NEFA and liver TG concentrations are associated with a slow rate of increase in DMI early postpartum (Vazquez-Anon et al., 1994). It can then be anticipated that a cow with poor feed intake prepartum will have poor intake postpartum and altered hepatic fat metabolism.

Although cows fed FL had greater intake of lipids than those fed CO (due to similar DMI but greater concentration of ether extract in the FL diet), liver total lipids concentration was similar for both diets. Douglas et al. (2004) previously reported that supplemental fat fed prepartum had no effect on peripartal lipid and TG accumulation in liver tissue of dairy cows with similar DMI. On the other hand, liver concentrations of TG in wk 4 were lower and those of glycogen on wk 2 and 4 postpartum were higher for multiparous cows fed FL than for those fed CO. Lignans contained in sesame oil have been linked to a decrease in liver total lipids in rats (Shankar et al., 2004). Flaxseed, which is rich in lignans (Axelson et al., 1982), could have similar effects and it could contribute to modifying liver lipid metabolism, thus decreasing liver TG concentrations.

Multiparous cows fed EB had lower DMI and plasma glucose concentrations postpartum than those fed the other diets, in agreement with the observation that decreased DMI is associated with hypoglycemia (Hayirli and Grummer, 2004). In general, cows fed EB performed poorly compared with those fed FL and CO as shown by lower postcalving DMI and milk yield and a more negative energy balance. Cows fed EB had higher milk fat concentration, which is consistent with lower DMI and higher NEFA concentration in blood. Lower feed intake may have contributed to increased concentrations of blood NEFA and BHBA and concentrations of liver TG and total lipids in multiparous cows. Increasing DMI or concentrations of plasma glucose and decreasing plasma concentrations of NEFA and BHBA may be important for preventing hepatic lipidosis (Bobe et al., 2004). Blood concentrations of BHBA are known to have an inhibitory effect on adipose tissue lipolysis in early lactation (Metz and Van den Bergh, 1977). This may imply that multiparous cows fed EB had greater adipose tissue lipolysis as indicated by their higher concentrations of BHBA and NEFA in plasma than those fed CO and FL. Multiparous cows had higher liver TG concentrations than primiparous cows, as previously reported by Vandehaar et al. (1999), which may be the result of multiparous cows having more adipose tissue at calving, higher milk production, longer calving intervals, weaker immune responses, or a lower antioxidant status, all of which are independent risk factors for fatty liver (Bobe et al., 2004).

Dietary PUFA are well known to reduce lipid accumulation in the liver, up-regulating FA oxidation in liver and skeletal muscle and increasing total body glycogen storage (Jump and Clarke, 1999). However, differences in FA composition of fat supplements could result in different oxidation of FA in the liver. Clouet et al. (1989) reported preferential mitochondrial oxidation of C18:3 in vitro and Yamazaki et al. (1987) found that n-3 FA increase peroxisomal $\beta$-oxidation activity in rat liver, thus suggesting that dietary n-3 FA are readily, and perhaps preferentially, oxidized compared with other FA. Feeding flaxseed could then increase oxidation of FA in the liver of cows, resulting in significantly lower liver TG concentrations in wk 4 postpartum.

Higher plasma relative percentages of C18:3n-3 would agree with the higher relative percentages of C18:3n-3 in milk fat of cows fed FL compared with those fed the other diets. Flaxseed contains around 55\% of total FA as n-3, which would contribute to an increase in relative percentage in blood once absorbed as previously reported (Petit, 2002). Mashek et al. (2005) reported higher hepatic relative percentages of $\mathrm{C} 18: 3$ when cows were intravenously infused with linseed oil compared with infusions of either tallow or fish oil.

In general, treatments had more significant effects on liver FA profiles of multiparous than primiparous cows probably because adipose tissue lipolysis is more important for the former (Vandehaar et al., 1999). In fact, Rukkwamsuk et al. (1999) found greater changes in liver FA percentages when adipose tissue lipolysis was increased. Changes over time and treatment effects were generally similar for liver relative percentages of C16:0 and C18:1 (increase over time) and for those of C18:0 and C18:2 (decrease over time). Similarly, Rukkwamsuk et al. (1999) observed a shift in liver percentages of C18:1 and C18:2 although the effect was observed only in cows with intense adipose tissue lipolysis. As reported by Rukkwamsuk et al. (1999, 2000), only minor differences were found before parturition in 
the percentages of each FA in the liver among treatments, thus corroborating the fact that diets fed during the dry period have little effect on the FA composition in the liver of cows before parturition. However, substantial changes occurred after calving in multiparous cows. According to Rukkwamsuk et al. (1999), a higher percentage of $\mathrm{C} 16: 0$ after parturition indicates that this FA originally is derived from the lipolysis of adipose tissue. Plasma NEFA concentrations were increased in the liver of postpartum multiparous cows fed EB, which would indicate that adipose tissue lipolysis was increased. Increased lipolysis of adipose tissue in cows fed EB compared with those fed $\mathrm{CO}$ and FL also resulted in lower liver relative percentages of C18:0, in agreement with the results of Rukkwamsuk et al. (1999).

Rukkwamsuk et al. (2000) reported that more intensive adipose tissue lipolysis results in increased relative percentages of C16:0, C18:0, C18:1, and C18:2 in blood, and that these FA, excluding C18:0, greatly accumulate in the liver. Multiparous cows fed EB showed more signs of adipose tissue lipolysis and they also had greater plasma relative percentages of $\mathrm{C} 16: 0$ and $\mathrm{C} 18: 1$ but they had lower relative percentages of C18:0 and C18:2 than those fed FL, which disagrees with results of Rukkwamsuk et al. (2000). However, the general positive relationship observed between plasma and liver profiles is in agreement with the results of Rukkwamsuk et al. (2000).

According to Wendel and Belury (2006), the ratios of 16:1/16:0 and 18:1/18:0 FA are reduced in the liver of rats with low, compared with high, liver lipids, suggesting that low ratios may result in a lower incidence of fatty liver in cows. Although the ratio of 16:1/16:0 in the liver was similar among treatments, the 18:1/18:0 FA ratio was significantly lower for multiparous cows fed $\mathrm{CO}$ and FL in wk 4 postpartum compared with those fed EB. These results would corroborate that multiparous cows fed EB compared with those fed $\mathrm{CO}$ and FL would be more likely to develop fatty liver as shown by high concentrations of BHBA and NEFA in plasma and TG in liver and low concentrations of plasma glucose and liver glycogen.

\section{CONCLUSIONS}

Feeding an energy booster during the transition period decreased postcalving feed intake and milk production compared with feeding whole flaxseed or no fat supplement and increased concentration of milk fat compared with feeding flaxseed. Transition cows fed whole flaxseed and no fat supplement had similar DMI, milk yield, and milk composition. Multiparous cows fed energy booster had higher concentrations of blood
NEFA and BHBA and liver total lipids and triglycerides, lower concentrations of blood glucose, and a more negative energy balance than those fed no fat or flaxseed. Multiparous cows fed whole flaxseed had higher liver concentrations of glycogen in wk 2 and 4 after calving and lower concentrations of triglycerides in wk 4 after calving compared with those fed no fat supplement or energy booster. In general, the effects of diets were more important for multiparous than primiparous cows. Feeding flaxseed compared with no fat or a source of saturated fatty acids from 6 wk before calving was a useful strategy to increase liver concentrations of glycogen and decrease those of triglycerides after calving, which may help to prevent the development of fatty liver in the transition dairy cow. However, the residual effects of feeding flaxseed during the transition period on health and productivity of the dairy cow still need to be determined over the lactation period.

\section{ACKNOWLEDGMENTS}

The authors thank L. Veilleux, D. Beaudry, S. Dallaire, and N. Beswick for technical assistance. They are also grateful to J. B. Andersen (Danish Institute of Agricultural Science, Department of Animal Health and Welfare, Research Centre Foulum, Denmark) for his guidance in the analysis of liver glycogen. This project was sponsored in part by Dairy Farmers of Canada and the Matching Investment Initiative of Agriculture and Agri-Food Canada.

\section{REFERENCES}

Andersen, J. B., D. G. Mashek, T. Larsen, M. O. Nielsen, and K. L. Ingvartsen. 2002. Effects of hyperinsulinaemia under euglycaemic condition on liver fat metabolism in dairy cows in early and mid-lactation. J. Vet. Med. A 49:65-71.

AOAC. 1990. Official Methods of Analysis. 15th ed. AOAC, Washington, DC.

Axelson, M., J. Sjovall, E. E. Gustafsson, and K. D. R. Setchell. 1982. Origin of lignans in mammals and identification of a precursor from plants. Nature 298:659-660.

Bertics, S. J., R. R. Grummer, C. Cadorniga-Valino, and E. E. Stoddard. 1992. Effect of prepartum dry matter intake on liver triglyceride concentration and early lactation. J. Dairy Sci. 75:19141922.

Bobe, G., J. W. Young, and D. C. Beitz. 2004. Pathology, etiology, prevention, and treatment of fatty liver in dairy cows. J. Dairy Sci. 87:3105-3124.

Canadian Council on Animal Care (CCAC). 1993. Guide to the Care and Use of Experimental Animals. Vol. 1. E. D. Olfert, B. M. Cross and A. A. McWilliam, ed. CCAC, Ottawa, Ontario, Canada.

Chouinard, P. Y., V. Girard, and G. J. Brisson. 1997. Performance and profiles of milk fatty acids of cows fed full-fat, heat-treated soybeans using various processing methods. J. Dairy Sci. 80:334-342.

Clouet, P., I. Niot, and J. Bézard. 1989. Pathway of alpha-linolenic acid through the mitochondrial outer membrane in the rat liver and influence on the rate of oxidation. Comparison with linoleic and oleic acids. Biochem. J. 263:867-873.

Delbecchi, L., C. E. Ahnadi, J. J. Kennelly, and P. Lacasse. 2001. Milk fatty acid composition and mammary lipid metabolism in 
Holstein cows fed protected or unprotected canola seeds. J. Dairy Sci. 84:1375-1381.

Dhiman, T. R., L. D. Satter, M. W. Pariza, M. P. Galli, K. Albridht, and M. X. Tolosa. 2000. Conjugated linoleic acid (CLA) content of milk from cows offered diets rich in linoleic and linolenic acid. J. Dairy Sci. 83:1016-1027.

Douglas, G. N., T. R. Overton, H. G. Bateman, II, and J. K. Drackley. 2004. Peripartal metabolism and production of Holstein cows fed diets supplemented with fat during the dry period. J. Dairy Sci. 7:4210-4220.

Douglas, G. N., T. R. Overton, H. G. Bateman, II, H. M. Dann, and J. K. Drackley. 2006. Prepartal plane of nutrition, regardless of dietary energy source, affects periparturient metabolism and dry matter intake in Holstein cows. J. Dairy Sci. 89:2141-2157.

Grummer, R. R. 1993. Etiology of lipid-related metabolic disorders in periparturient dairy cows. J. Dairy Sci. 76:3882-3896.

Hayirli, A., and R. R. Grummer. 2004. Factors affecting dry matter intake prepartum in relationship to etiology of peripartum lipidrelated metabolic disorders: A review. Can. J. Anim. Sci. 84:337-347.

Hayirli, A., R. R. Grummer, E. V. Nordheim, and P. M. Crump. 2002. Animal and dietary factors affecting feed intake during the prefresh transition period in Holsteins. J. Dairy Sci. 85:34303443.

Jump, D. B., and S. D. Clarke. 1999. Regulation of gene expression by dietary fat. Annu. Rev. Nutr. 19:63-90.

Kumamoto, T., and T. Ide. 1998. Comparative effects of $\alpha$ - and $\gamma$ linolenic acids on rat liver fatty acid oxidation. Lipids 33:647-654

Lambert, M. S., M. A. Avella, K. M. Botham, and P. A. Mayes. 1998. Comparison of short- and long-term effects of different dietary fats on hepatic uptake and metabolism of chylomicron remnants in rats. Br. J. Nutr. 79:203-211.

Malewiak, M. I., R. Rozen, X. Lle Liepvre, and S. Griglio. 1988. Oleate metabolism and endogenous triacylglycerol hydrolysis in isolated hepatocytes from rats fed a high-fat diet. Diabetes Metab. 14:270-276.

Mashek, D. G., S. J. Bertics, and R. R. Grummer. 2002. Metabolic fate on long-chain unsaturated fatty acids and their effects on palmitic acid metabolism and gluconeogenesis in bovine hepatocytes. J. Dairy Sci. 85:2283-2289.

Mashek, D. G., S. J. Bertics, and R. R. Grummer. 2005. Effects of intravenous triacylglycerol emulsions on hepatic metabolism and blood metabolites in fasted dairy cows. J. Dairy Sci. 88:100-109.

Mashek, D. G., and R. R. Grummer. 2003. Effects of different long chain fatty acids on lipid metabolism and gluconeogenesis in monolayer cultures of bovine hepatocytes. J. Dairy Sci. 86:2390-2396.

McCutcheon, S. N., and D. E. Bauman. 1986. Effect of chronic growth hormone treatment on response to epinephrine and thyrotropinreleasing hormones in lactating cows. J. Dairy Sci. 69:44-51.

Metz, S. H. M., and S. G. Van den Bergh. 1977. Regulation of fat mobilization in adipose tissue of dairy cows in the period around parturition. Neth. J. Agric. Sci. 25:198-211.

National Research Council. 2001. Nutrient Requirements of Dairy Cattle. 7th rev. ed. Nat. Acad. Press, Washington, DC.

Park, P. W., and R. E. Goins. 1994. In situ preparation of fatty acid methyl esters for analysis of fatty acid composition in foods. J. Food Sci. 59:1262-1266.
Petit, H. V. 2002. Digestion, Milk production, milk composition, and blood composition of dairy cows fed whole flaxseed. J. Dairy Sci. $85: 1482-1490$.

Rukkwamsuk, T., M. J. H. Geelen, T. A. M. Kruip, and T. Wensing. 2000. Interrelation of fatty acid composition in adipose tissue, serum, and liver of dairy cows during the development of fatty liver postpartum. J. Dairy Sci. 83:52-59.

Rukkwamsuk, T., T. Wensing, and M. J. H. Geelen. 1999. Hepatic fatty acid composition in periparturient dairy cows with fatty liver induced by intake of a high energy diet in the dry period. J. Dairy Sci. 82:280-287.

SAS Institute. 2000. Release 8.02. SAS Institute Inc., Cary, NC.

Selberg, K. T., A. C. Lowe, C. R. Staples, N. D. Luchini, and L. Badinga. 2004. Production and metabolic responses of periparturient Holstein cows to dietary conjugated linoleic acid and transoctadecenoic acids. J. Dairy Sci. 87:158-168.

Shankar, S. V., B. R. Lokesh, and K. Sambaiah. 2004. Influence of sesame oil on serum and liver lipids and tocopherol levels in rats. J. Food Sci. Technol. 41:516-520.

Skaar, T. C., R. R. Grummer, M. R. Dentine, and R. H. Stauffacher. 1989. Seasonal effects of prepartum and postpartum fat and niacin feeding on lactation performance and lipid metabolism. J. Dairy Sci. 72:2028-2038.

Tabacco, A., F. Meiattini, E. Moda, and P. Tarli. 1979. Simplified enzymic/colorimetric serum urea nitrogen determination. Clin. Chem. 25:336-337.

Trinder, P. 1969. Determination of glucose in blood using glucose oxidase with an alternative oxygen acceptor. Ann. Clin. Biochem. 6:24-27.

Van Den Top, A. M., M. J. H. Geelen, T. Wensing, G. H. Wentink, A. T. van't Klooster, and A. C. Beynen. 1996. Higher postpartum hepatic triacylglycerol concentrations in dairy cows with free rather than restricted access to feed during the dry period are associated with lower activities of hepatic glycerol-phosphate acyltransferase. J. Nutr. 126:76-85.

Van Soest, P. J., J. B. Robertson, and B. A. Lewis. 1991. Methods for dietary fiber, neutral detergent fiber, and nonstarch polysaccharides in relation to animal nutrition. J. Dairy Sci. 74:35833597.

Vandehaar, M. J., G. Yousif, B. K. Sharma, T. H. Herdt, R. E. Emery, M. S. Allen, and J. S. Liesman. 1999. Effects of energy and protein density of prepartum diets on fat and protein metabolism of dairy cattle in the periparturient period. J. Dairy Sci. 82:1282-1295.

Vazquez-Anon, M., S. J. Bertics, M. Luck, and R. R. Grummer. 1994. Peripartum liver triglycerides and plasma metabolites. J. Dairy Sci. 77:1521-1528.

Wendel, A. A., and M. A. Belury. 2006. Effects of conjugated linoleic acid and troglitazone on lipid accumulation and composition in lean and Zucker diabetic fatty ( $f a / f a$ ) rats. Lipids 41:241-247.

Williamson, D. H., J. Mellanby, and H. A. Krebs. 1962. Enzymatic determination of $D(-) \beta$-hydroxybutyric acid and acetoacetic acid in blood. Biochem. J. 82:90-98.

Yamazaki, R. K., T. Shen, and G. B. Schade. 1987. A diet rich in (n3 ) fatty acids increases peroxisomal beta-oxidation activity and lowers plasma triacylglycerols without inhibiting glutathione-dependent detoxication activities in the rat liver. Biochim. Biophys. Acta 920:62-67. 